\title{
Aspergillus nodules; another presentation of Chronic Pulmonary Aspergillosis
}

\author{
Eavan G. Muldoon ${ }^{1,4^{*}}$, Anna Sharman², lain Page ${ }^{1,4}$, Paul Bishop ${ }^{3}$ and David W. Denning ${ }^{1,4}$
}

\begin{abstract}
Background: There are a number of different manifestations of pulmonary aspergillosis. This study aims to review the radiology, presentation, and histological features of lung nodules caused by Aspergillus spp.

Methods: Patients were identified from a cohort attending our specialist Chronic Pulmonary Aspergillosis clinic. Patients with cavitating lung lesions, with or without fibrosis and those with aspergillomas or a diagnosis of invasive aspergillosis were excluded. Demographic, laboratory, and clinical data and radiologic findings were recorded.

Results: Thirty-three patients with pulmonary nodules and diagnostic features of aspergillosis (histology and/or laboratory findings) were identified. Eighteen (54.5\%) were male, mean age 58 years (range 27-80 years). 19 (57.6 \%) were former or current smokers. The median Charleston co-morbidity index was 3 (range 0-7). All complained of a least one of; dyspnoea, cough, haemoptysis, or weight loss. None reported fever. Ten patients (31\%) did not have an elevated Aspergillus lgG, and only 4 patients had elevated Aspergillus precipitins. Twelve patients (36 \%) had a single nodule, six patients (18\%) had between 2 and 5 nodules, 2 (6\%) between 6 and 10 nodules and $13(39 \%)$ had more than 10 nodules. The mean size of the nodules was $21 \mathrm{~mm}$, with a maximum size ranging between $5-50 \mathrm{~mm}$. No nodules had cavitation radiographically. The upper lobes were most commonly involved. Histology was available for 18 patients and showed evidence of granulation tissue, fibrosis, and visualisation of fungal hyphae.
\end{abstract}

Conclusion: Pulmonary nodules are a less common manifestation of aspergillosis in immunocompetent patients. Distinguishing these nodules from other lung pathology may be difficult on CT findings alone.

Keywords: Aspergillus, Pulmonary nodule, Fungal infection of lung, Chronic pulmonary aspergillosis

\section{Background}

There are a number of manifestations of pulmonary aspergillosis [1]. Aspergillus spp. are ubiquitous in the environment and exposure to conidia is common. However, only a minority of people develop clinical disease, and this is often determined by host characteristics, e.g. immune compromise, genetic predisposition, underlying lung pathology, and prior pulmonary infection such as tuberculosis (TB). Classically chronic pulmonary aspergillosis (CPA) in immunocompetent patients presents as a saprophytic infection in a pre-existing cavity,

\footnotetext{
* Correspondence: Eavan@esatclear.ie; Eavan.muldoon@manchester.ac.uk ${ }^{1}$ The National Aspergillosis Centre, University Hospital of South Manchester, 2nd floor ERC, Southmoor Road, Wythenshawe M23 9LT, UK

${ }^{4}$ The University of Manchester and the Manchester Academic Health Service Centre, University Hospital of South Manchester, Southmoor Road, Wythenshawe M23 9LT, UK

Full list of author information is available at the end of the article
}

often following an infection such as TB or prior lung surgery. There are a number of recognised manifestations of CPA; subacute invasive pulmonary aspergillosis (SAIA) [which may be referred to as chronic necrotising pulmonary aspergillosis (CNPA)], chronic cavitary pulmonary aspergillosis (CCPA) and chronic fibrosing pulmonary aspergillosis (CFPA) [2]. Subacute IPA occurs in the setting of some degree of immune compromise, and may present with nodules, consolidation and or cavitation on chest imaging, and a more rapidly progressive clinical course. CCPA presents with single or multiple cavities, with or without aspergilloma(s), and CFPA has this appearance with the additive features of pulmonary fibrosis, which may be progressive and destructive.

Estimates of the incidence and prevalence of CPA are difficult; however the global burden of disease is 
increasingly being recognised [3, 4]. For example, the proportion of patients with TB as an underlying risk factor for the development of CPA will vary depending on geographical location [5]. In 2011, CPA was estimated to affect 3600 patients in the UK, based on estimates of prior TB, and diagnoses of sarcoidosis [6], and 1.2 million worldwide after TB [3] and 72,000 complicating fibrocystic pulmonary sarcoidosis [4].

There is a paucity of knowledge on CPA which presents as single or multiple nodule(s) without cavitation in immune competent hosts. The published literature is limited to case reports and small case series. Often, in these cases the diagnosis is made following removal or biopsy of the nodule(s) which is presumed to be malignant $[7,8]$. In the largest case series from Korea, eleven patients with solitary pulmonary nodules were reviewed [9]. Three of the eleven patients had some evidence of cavitation on CT imaging, and all had histologically proven Aspergillus infection. In a second Korean series, seven patients were identified with biopsy proven Aspergillus disease, in the absence of immunosuppression or underlying lung disease [10]. Unfortunately in neither series was a correlation made with Aspergillus IgG (precipitins), which is a cornerstone of the diagnosis of CPA [2].

The purpose of this study is to review the clinical characteristics, histological and radiological features of pulmonary nodules caused by Aspergillus spp.

\section{Methods}

Patients attending our specialist CPA clinic in the National Aspergillosis Centre (NAC) with nodular Aspergillus disease were identified. The NAC is nationally commissioned to provide specialist care for patients with chronic pulmonary aspergillosis in the UK. There are currently approximately 350 patients in follow up care of the NAC with CPA, and approximately 100 new patients referred annually. Patients were identified by one of two methods. First, patients with pulmonary nodules on chest imaging at presentation, and features consistent with a diagnosis of aspergillosis (i.e. biopsy proven disease and/or positive Aspergillus serology and/or Aspergillus spp isolated form respiratory secretions) were prospectively recorded. Second, additional case finding was performed by the retrospective review of patient correspondence and review of histopathology records. A rounded opacity, well or poorly defined, measuring up to $3 \mathrm{~cm}$ in diameter was defined as a nodule as per the Fleischner Society: Glossary of Terms for Thoracic Imaging [11]. Patients with aspergillomas and those with cavitating lung lesions, with or without fibrosis were excluded. Patients with a diagnosis of invasive aspergillosis were also excluded. Demographic data, details of the clinical presentation, laboratory data and radiologic findings were recorded on each patient. All radiology was reviewed by a consultant radiologist (AS) for accuracy. The ImmunoCap $^{\text {tw }}$ assay (Phadia, Uppsala, Sweden) was used to measure A. fumigatus IgG and the Microgen antigens and counterimmunoelctrophoresis (MIcrogen, Camberley, Surrey, UK) for Aspergillus precipitins. Serum mannose binding lectin $(\mathrm{MBL})$ concentrations were measured by ELISA (MBL Oligomer ELISA Kit, BioPorto Diagnostics, DK), upper and lower reported detection limit of 4.00 and $0.05 \mathrm{mg} / \mathrm{L}$ respectively. For culture, sputum was digested with Sputasol ${ }^{\circ}$ (ratio 1:1), vortexed, and $10 \mu \mathrm{L}$-streaked on two Sabouraud dextrose agar plates [12] and incubated at $30{ }^{\circ} \mathrm{C}$ and $37^{\circ} \mathrm{C}$ for 7 days, and on bacterial media. For quantitative PCR, the MycXtra kit (Myconostica, Cambridge, UK) was used for DNA extraction using 0.5$3 \mathrm{~mL}$ of sample. DNA was eluted in $40 \mu \mathrm{L}$ and $10 \mu \mathrm{L}$ used for quantitative PCR. The MycAssay Aspergillus kit (Myconostica) was used following the manufacturer's instructions; a crossing threshold (Ct) of $>38$ was negative, Ct from $36-38$ a weak positive and $<36$ was interpreted as a strong positive [13]. The data were collected in Microsoft excel, and data analysis performed using SPSS version 20. This report is a retrospective evaluation of all patients who were managed with Aspergillus nodules, and as such is exempt from ethical review or patient consent.

\section{Results}

Thirty three patients with lung nodules and features diagnostic of CPA (histology and/or laboratory findings) were identified. Ten patients had proven disease, and the remainder deemed probable disease, based on serology and culture results (Table 1). Eighteen (54.5\%) of patients were male, the mean age was 58 years (range 27-80 years). Nineteen (57.6\%) were current or exsmokers, in 9 (27.3\%) smoking history was not documented. The median Charleston co-morbidity index was 3 (range $0-7$ ). On presentation all patients complained of a least one of the following symptoms; dyspnoea, cough, haemoptysis, or weight loss. Twenty nine patients (88 \%) reported cough, 23 (70 \%) dyspnoea, 11 (33\%) described weight loss, and 5 (15\%) haemoptysis. No patients reported a history of fever.

\section{Radiological features}

All patients had computer tomography (CT) performed. Twenty patients $(60 \%)$ had upper lobe disease alone, with either unilateral or bilateral involvement. In seven patients $(6 \%)$ all lobes were involved, the remaining patients had variable patterns of lobar involvement. In twelve patients $(36 \%)$ a single nodule was present, six (18\%) patients had between 2 and 5 nodules, 2 (6\%) had between 6 and 10 nodules and 13 (39\%) patients more than 10 nodules. The maximum nodule size 
Table 1 Characteristic of patients diagnosed with Aspergillus nodule(s)

\begin{tabular}{|c|c|c|c|c|c|c|c|c|c|c|c|c|}
\hline Patient & $\begin{array}{l}\text { Number } \\
\text { of nodules }\end{array}$ & $\begin{array}{l}\text { Lobes } \\
\text { of lung } \\
\text { involved }\end{array}$ & $\begin{array}{l}\text { Min } \\
\text { size }(\mathrm{mm})\end{array}$ & $\begin{array}{l}\text { Max } \\
\text { size (mm) }\end{array}$ & Lymphadenopathy & $\begin{array}{l}\text { Visible on } \\
\text { concurrent CXR }\end{array}$ & Symptoms & $\begin{array}{l}\text { Aspergillus } \\
\lg G\end{array}$ & $\begin{array}{l}\text { Sputum } \\
\text { culture }\end{array}$ & $\begin{array}{l}\text { Aspergillus } \\
\text { PCR }\end{array}$ & $\begin{array}{l}\text { Tissue } \\
\text { Specimen }\end{array}$ & Results \\
\hline \multicolumn{13}{|c|}{ Aspergillus Nodules } \\
\hline 1 & 1 & LLL & & 11 & $\mathrm{~N}$ & Y & None & 76 & & $n / a$ & lung & fibrosis, fungal hyphae \\
\hline 2 & 2 & $\begin{array}{l}\text { Upper lobes } \\
\text { bilaterally }\end{array}$ & 4 & 10 & $n$ & y & None & 68 & & Negative & lung & $\begin{array}{l}\text { granuloma, necrosis, } \\
\text { fungal hyphae }\end{array}$ \\
\hline 3 & 1 & LUL & & 16 & $n$ & y & $\begin{array}{l}\text { Dyspnoea, cough, } \\
\text { weight loss }\end{array}$ & 14 & & Negative & lung & $\begin{array}{l}\text { Inflammation, fungal } \\
\text { hyphae }\end{array}$ \\
\hline 4 & 2 & RUL & & 7 & $\mathrm{n}$ & y & Cough, weight loss & 40 & & Negative & Lung & $\begin{array}{l}\text { Inflammation } \\
\text { granulomatous }\end{array}$ \\
\hline 5 & 1 & RUL & & 16 & $n$ & y & Dyspnoea, weight loss & 101 & & $\mathrm{n} / \mathrm{a}$ & lung & COP, fungal hyphae \\
\hline 6 & 1 & RUL & & 12 & $\mathrm{n}$ & y & $\begin{array}{l}\text { Dyspnoea, cough, } \\
\text { haemoptysis }\end{array}$ & N/A & A. fumigatus & $\mathrm{n} / \mathrm{a}$ & BAL & $\begin{array}{l}\text { inflammatory infiltrate } \\
\text { fungal hyphae }\end{array}$ \\
\hline 7 & 1 & LUL & & 22 & $n$ & y & Dyspnoea, cough & 22 & & N/A & lung & $\begin{array}{l}\text { fibrosis, granulomata, } \\
\text { necrosis, fungal hyphae }\end{array}$ \\
\hline 8 & 1 & RUL & & 22 & $n$ & y & $\begin{array}{l}\text { Dyspnoea, cough, } \\
\text { haemoptysis }\end{array}$ & 86 & & Negative & lung & $\begin{array}{l}\text { Inflammation, fungal } \\
\text { hyphae }\end{array}$ \\
\hline 9 & 3 & $\begin{array}{l}\text { Upper lobes } \\
\text { bilaterally }\end{array}$ & 6 & 27 & $n$ & y & $\begin{array}{l}\text { Dyspnoea, cough, } \\
\text { weight loss }\end{array}$ & 54 & A. fumigatus & Negative & lung & fungal hyphae, necrosis \\
\hline 10 & 1 & LLL & & 25 & $\begin{array}{l}\text { could not } \\
\text { visualise }\end{array}$ & y & Dyspnoea, cough & 23 & A. fumigatus & Positive & Lung & $\begin{array}{l}\text { Inflammation } \\
\text { granulomatous }\end{array}$ \\
\hline 11 & 2 & LUL & 9 & 35 & $n$ & y & Dyspnoea, cough & 32 & & $\begin{array}{l}\text { Weak } \\
\text { positive }\end{array}$ & Lung & $\begin{array}{l}\text { Inflammation } \\
\text { granulomatous }\end{array}$ \\
\hline \multicolumn{13}{|c|}{ Probable Aspergillus Nodules } \\
\hline 12 & 4 & All lobes & 2 & 38 & y & y & $\begin{array}{l}\text { Dyspnoea, cough, } \\
\text { haemoptysis }\end{array}$ & 185 & & Positive & & \\
\hline 13 & 2 & $\begin{array}{l}\text { Upper lobes } \\
\text { bilaterally }\end{array}$ & 3 & 9 & $n$ & N/A & Cough & 87 & & Negative & & \\
\hline 14 & 4 & $\begin{array}{l}\text { All lobes } \\
\text { except RUL }\end{array}$ & 2 & 16 & $\mathrm{n}$ & y & Dyspnoea, cough & 49 & & $n / a$ & BAL & $\begin{array}{l}\text { benign cells, } \\
\text { polymorphs }\end{array}$ \\
\hline 15 & 2 & $\begin{array}{l}\text { Upper lobes } \\
\text { bilaterally }\end{array}$ & 7 & 12 & y & y & Dyspnoea, cough & 68 & & Negative & & \\
\hline 16 & 4 & $\begin{array}{l}\text { all lobes } \\
\text { except RML }\end{array}$ & 5 & 16 & $n$ & Y & Dyspnoea, cough & 65 & $\begin{array}{l}\text { A. nidulans, } \\
\text { A. niger }\end{array}$ & Negative & & \\
\hline 17 & 1 & LUL & & 14 & $n$ & Y & $\begin{array}{l}\text { Dyspnoea, cough, } \\
\text { weight loss }\end{array}$ & 152 & & N/A & BAL & $\begin{array}{l}\text { benign cells, } \\
\text { polymorphs }\end{array}$ \\
\hline 18 & 1 & RUL & & 10 & $\mathrm{n}$ & y & Cough, weight loss & 18 & & $\mathrm{n} / \mathrm{a}$ & & \\
\hline 19 & 4 & All lobes & 2 & 31 & Y & Y & $\begin{array}{l}\text { Dyspnoea, cough, } \\
\text { haemoptysis, weight } \\
\text { loss }\end{array}$ & 52 & A. fumigatus & $\begin{array}{l}\text { Weak } \\
\text { positive }\end{array}$ & lung & $\begin{array}{l}\text { haemosiderin } \\
\text { deposition }\end{array}$ \\
\hline 20 & 4 & $\begin{array}{l}\text { Upper lobes } \\
\text { bilaterally }\end{array}$ & 1 & 13 & $y$ & y & Dyspnoea, cough & 190 & A. fumigatus & $\begin{array}{l}\text { Weak } \\
\text { positive }\end{array}$ & lung & inflammatory debris \\
\hline
\end{tabular}


Table 1 Characteristic of patients diagnosed with Aspergillus nodule(s) (Continued)

\begin{tabular}{|c|c|c|c|c|c|c|c|c|c|c|c|c|}
\hline 21 & 4 & $\begin{array}{l}\text { All lobes } \\
\text { except RUL }\end{array}$ & 1 & 18 & $\mathrm{n}$ & $y$ & Dyspnoea, cough & 115 & A fumigatus & Positive & & \\
\hline 22 & 1 & LUL & & 16 & $\mathrm{n}$ & y & $\begin{array}{l}\text { Dyspnoea, cough, } \\
\text { weight loss }\end{array}$ & 19 & $\begin{array}{l}\text { A nidulans, } \\
\text { A.fumigatus }\end{array}$ & $\begin{array}{l}\text { Weak } \\
\text { positive }\end{array}$ & & r \\
\hline 23 & 4 & All lobes & 1 & 16 & y & $n$ & Dyspnoea, cough & 75 & & N/A & Lung & Emphysema bullous \\
\hline 24 & 1 & RUL & & 20 & $\mathrm{n}$ & y & Cough & 12 & $\begin{array}{l}\text { A. } \\
\text { fumigatuis }\end{array}$ & N/A & & \\
\hline 25 & 4 & All lobes & 1 & 20 & $y$ & $\mathrm{Y}$ & Cough & 170 & & Negative & & \\
\hline 26 & 4 & All lobes & 5 & 34 & $n$ & & $\begin{array}{l}\text { Dyspnoea, cough, } \\
\text { weight loss }\end{array}$ & 104 & & $\begin{array}{l}\text { Weak } \\
\text { positive }\end{array}$ & & \\
\hline 27 & 4 & All lobes & 1 & 5 & $\mathrm{n}$ & $y$ & Dyspnoea, cough & 42 & A. fumigatus & Positive & & \\
\hline 28 & 4 & RUL & 1 & 27 & $n$ & y & Cough, haemoptysis & 82 & & Positive & & \\
\hline 29 & 4 & $\begin{array}{l}\text { all except } \\
\text { RML, RLL }\end{array}$ & 1 & 28 & N & Y & Dyspnoea & 42.5 & & N/A & & \\
\hline 30 & 3 & LUL & 5 & 37 & $n$ & y & Cough & 106 & & Negative & & \\
\hline 31 & 1 & RUL & & 29 & $n$ & y & Cough & 18 & & Negative & & \\
\hline 32 & 4 & All lobes & 6 & 32 & $\mathrm{n}$ & y & $\begin{array}{l}\text { Dyspnoea, cough, } \\
\text { weight loss }\end{array}$ & 10 & & N/A & & \\
\hline 33 & 2 & LUL & 17 & 50 & $\mathrm{n}$ & N/A & $\begin{array}{l}\text { Dyspnoea, cough, } \\
\text { weight loss }\end{array}$ & 108 & & Negative & & \\
\hline
\end{tabular}


ranged between 5-50 mm, mean $21 \mathrm{~mm}$. Associated lymphadenopathy was present in six patients (18\%). Thirty patients had a plain chest film performed concurrently with the CT imaging, in 29/30 (97\%) the nodule was visible on plain film. Eight patients (24\%) had undergone positron emission tomography (PET) and in all cases the fluorodeoxyglucose (FDG) uptake was low to moderate (SVUmax <5.4). Twenty three patients (70 \%) had a solid mass on CT imaging (Fig. 1), while the remaining patients had a mixed pattern of disease. Eleven patients had findings consistent with emphysema on CT imaging. One patient initially had a cavitating lesion which became solid on repeat imaging (Fig. 2). Only
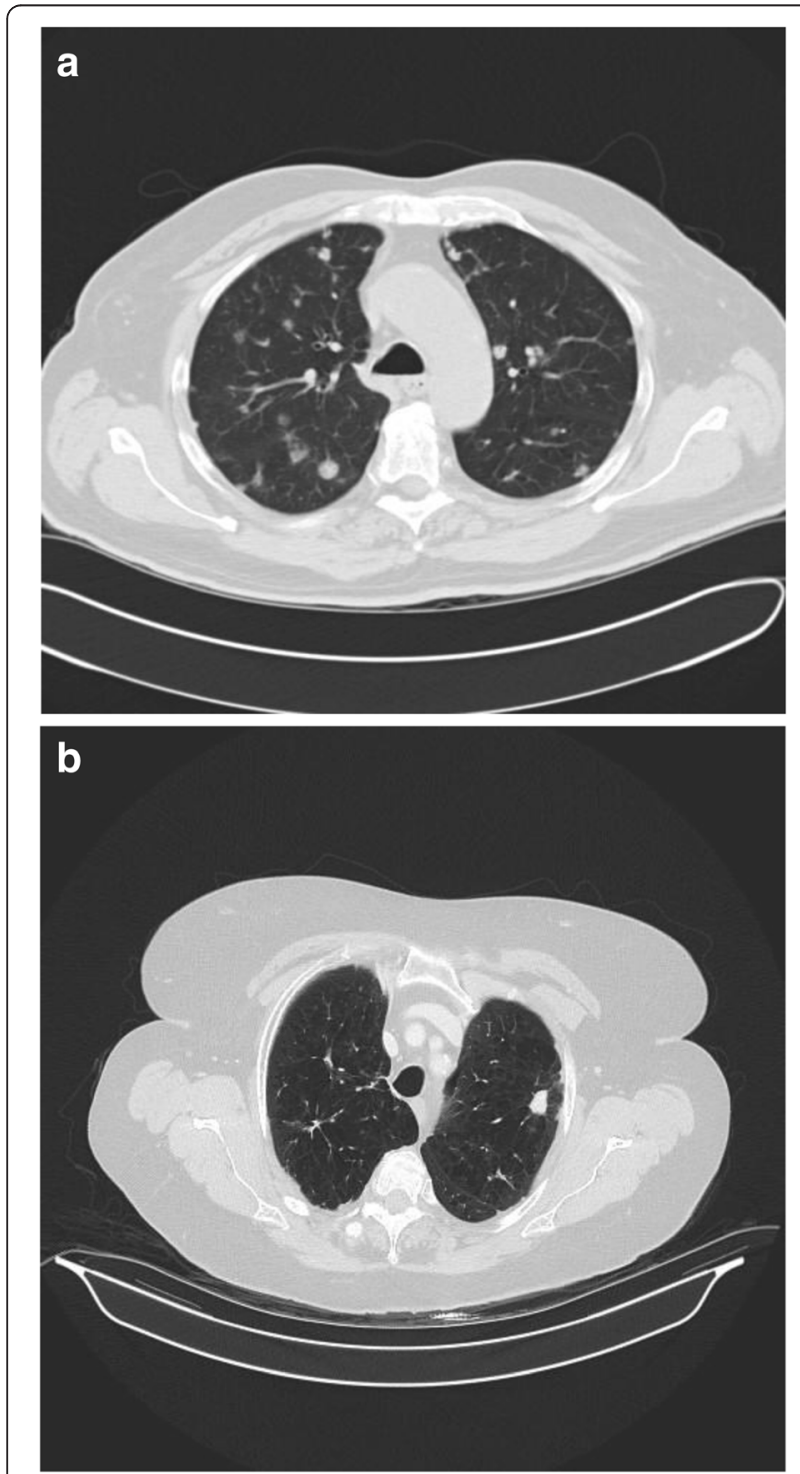

Fig. 1 Different patterns of Aspergillus nodule disease. A showing multiple nodules, B a single pulmonary nodule on background of emphysematous lungs
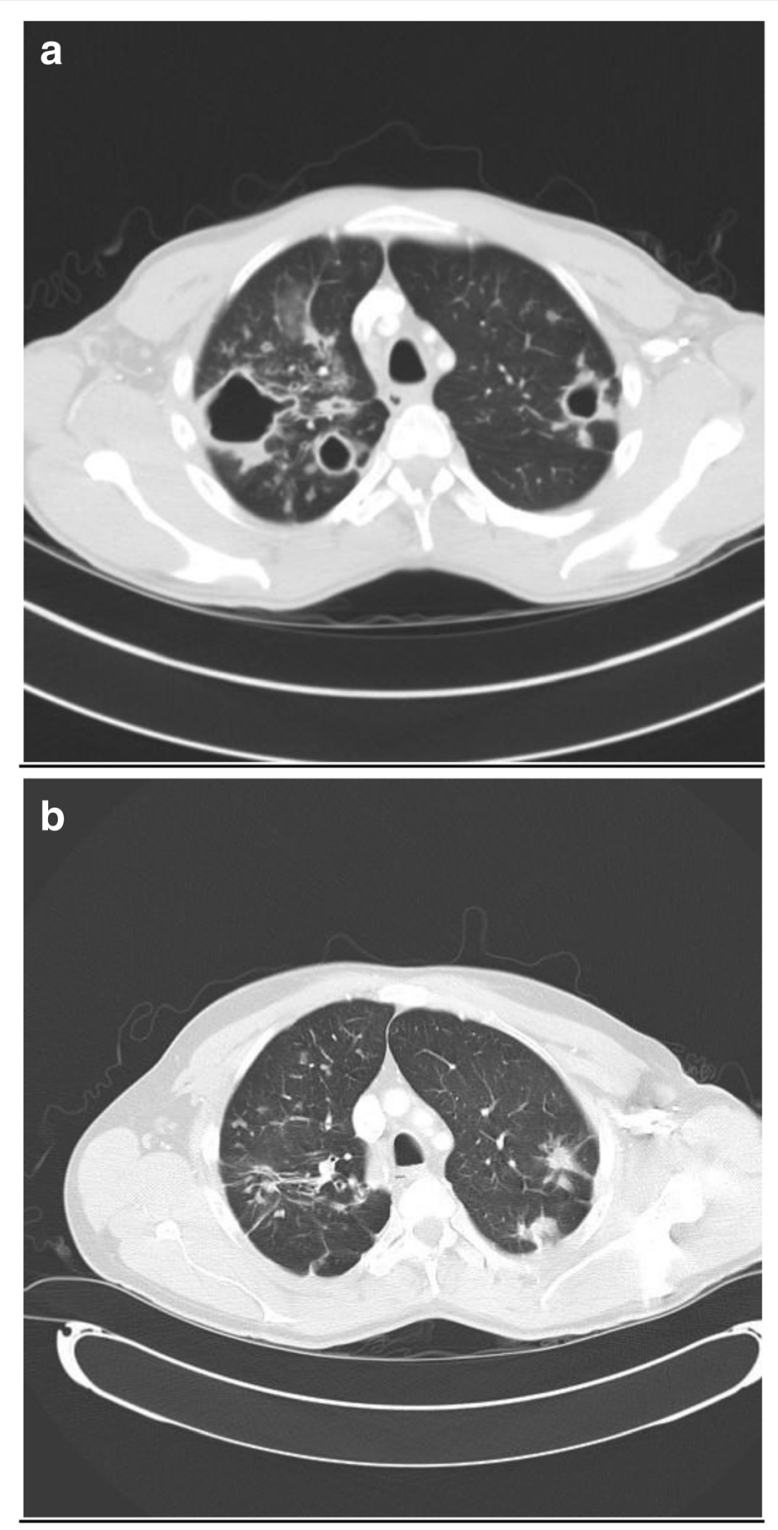

Fig. 2 CT imaging showing cavitating disease initially, which developed into nodular disease

one patient, with multiple nodules, had evidence of calcification within some nodules.

\section{Laboratory parameters}

Aspergillus IgG antibody results were available for 32 patients. In ten patients (31\%) the Aspergillus IgG was within normal limits (i.e. $\leq 40 \mathrm{mg} / \mathrm{L}$ ), including four patients with a result between $20 \mathrm{mg} / \mathrm{L}$ and $40 \mathrm{mg} / \mathrm{L}$. Aspergillus precipitins was positive in $4 / 32$ (12.5\%). Eight patients $(24 \%)$ had lymphopenia (lymphocyte count $\left.<1.5 \times 10^{9} / \mathrm{L}\right)$. Twenty nine patients had MBL measured, and 11/29 (38 \%) were deficient $(<1.0 \mathrm{mg} / \mathrm{L})$. Twenty nine patients submitted sputum samples for analysis. Nine of the 32 patients (31 \%) isolated an $A$. 
fumigatus from their sputum sample, one of whom also had $A$. nidulans isolated from their sputum. One patient had $A$. nidulans and $A$. niger isolated from his sputum samples. Sputum samples also yielded a number of bacterial organisms including $S$. aureus, $H$. influenzae, $H$. parainfluenzae, M. catarrhalis, S. marcescens, E. coli, K. pneumoniae, S. maltophilia, and P. aeruginosa. Seven patients had sputum samples which did not yield any growth of bacteria or fungi. Twenty two patients submitted sputum for Aspergillus PCR analysis, 10/22 (45 \%) were positive. In four cases (4/14) Aspergillus DNA was detected by PCR but there was no growth of Aspergillus spp. by culture.

\section{Histology}

Histology was available on sixteen patients. Thirteen (81 \%) had undergone lung biopsy, and the remainder had bronchoalveolar lavage (BAL) fluid analysed. Of those who had undergone lung biopsy, in 7/13 (54 \%) fungal hyphae were visualised. Granulomatous inflammation and/ or necrosis was seen in the remaining patients histology (Table 1). Of the three patients who had BAL washings available for analysis, one had fungal hyphae visualised in bronchial washings. Some had fruiting bodies (conidiophores with conidia) of Aspergillus identified (Fig. 3), suggesting that the original infection with Aspergillus occurred in an airspace or on an epithelial surface, and subsequently was filled in with inflammatory cells and Aspergillus hyphae.

\section{Surgery}

Nine patients underwent surgical resection of the lung nodule. One patient had recurrent disease identified on CT four years post operatively.

\section{Discussion}

In this, the largest published series of Aspergillus nodules to date, the characteristics of 33 patients were reviewed. These patients represent less than $10 \%$ of the cohort of patients with CPA cared for in the National Aspergillosis Centre. However, this may be an under representation of this presentation of CPA, as cases may not be recognised, have negative Aspergillus IgG or precipitins, and/or not undergo biopsy to secure their diagnosis. However, recognition of nodules on CT scanning of the thorax is becoming more common, as screening for lung cancer is more frequently undertaken. Many nodules identified on such screening scans are removed or biopsied and do not reveal malignancy. Aspergillus nodules are one such benign entity.

In those unable to undergo biopsy or resection because of poor respiratory reserve and a risk of pneumothorax, empirical radiotherapy is sometimes given for a 'PET positive' suspicious lesion. We have
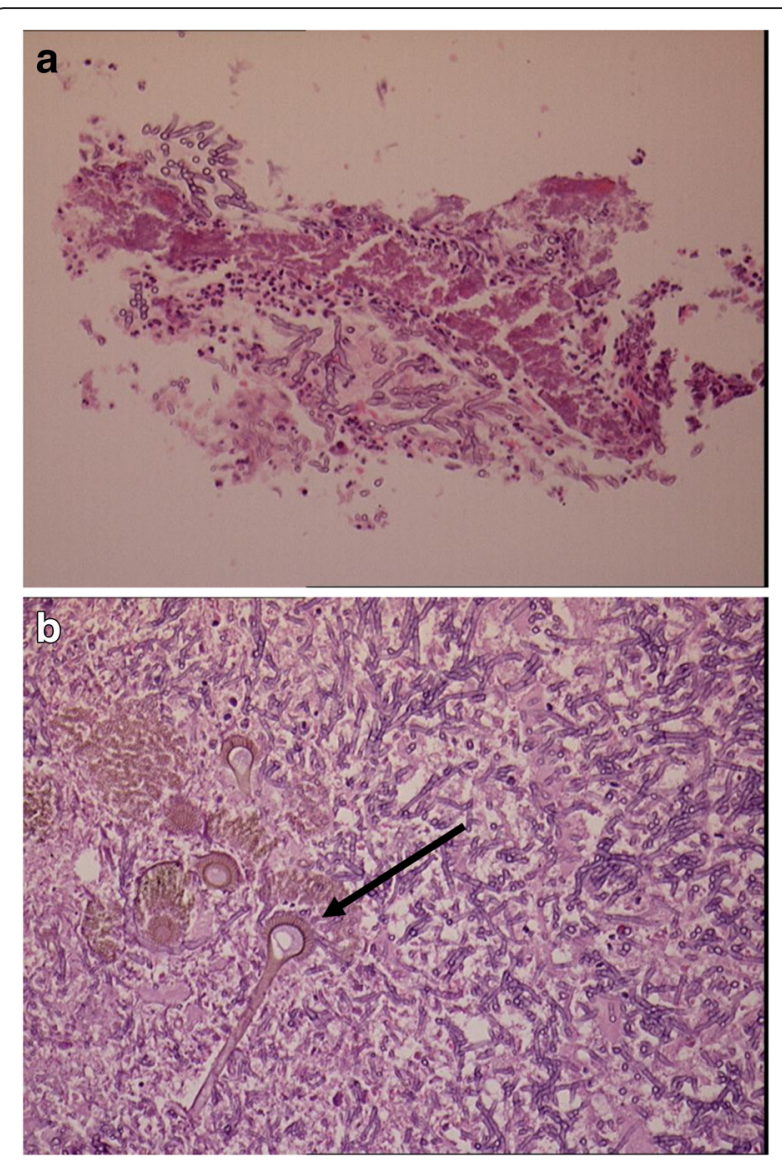

Fig. 3 Biopsy demonstrating inflammation and necrosis and fungal hyphae (low power) and fungal conidia (arrow) on high power

seen at least 2 patients with chronic pulmonary aspergillosis in the area of radiotherapy, which we suspect, but cannot prove, had an Aspergillus nodule that was irradiated. We would therefore encourage clinical oncologists to consider the possibility of an Aspergillus nodule before embarking on lung irradiation. The response to radiotherapy may not be entirely problematic however, as illustrated by a small series of CPA patients explicitly treated with radiotherapy [14].

A number of other infections may also present with pulmonary nodules, which may be difficult to distinguish on radiological features alone (Table 2). The relative frequency of the differential diagnoses varies substantially by geography. In endemic areas, other fungal infections can present with persistent pulmonary nodules of masses in apparently immunocompetent persons. The appearance of such fungal infections mimics malignancy and diagnosis is often confirmed on biopsy. At one centre in Texas, USA 17 of 2,098 (0.6 \%) persons presenting with pulmonary nodule were ultimately diagnosed with histoplasmosis, cryptococcosis or coccidiomycosis rather than malignancy [15]. Another case series describes 27 cases of 
Table 2 Infectious differential diagnosis of pulmonary nodules

\begin{tabular}{|c|c|c|c|}
\hline Cause of nodule/disease & Underlying disease(s), geography & $\mathrm{CT}$ characteristics & Evolution \\
\hline Aspergillus nodule & $\begin{array}{l}\text { Emphysema, asthma taking corticosteroids, } \\
\text { smoker. Not immunocompromised. Global }\end{array}$ & $\begin{array}{l}\text { Single or multiple nodules. May affect } \\
\text { any lobe, although upper lobes most } \\
\text { common. Unlikely to be calcified }\end{array}$ & $\begin{array}{l}\text { Slow to change. May cavitate } \\
\text { over many months. }\end{array}$ \\
\hline Coccidioidal nodule & $\begin{array}{l}\text { None. Visit to, or inhabitant of, } \\
\text { endemic area. }\end{array}$ & $\begin{array}{l}\text { Usually single, upper lobes. } \\
\text { Occasionally calcified. }\end{array}$ & Static over months or years. \\
\hline Histoplasma nodule & $\begin{array}{l}\text { None. Visit to, or inhabitant of, endemic } \\
\text { area. May report specific exposure e.g } \\
\text { bat cave }\end{array}$ & Single or multiple. Often calcified. & Static over months or years. \\
\hline $\begin{array}{l}\text { Nontuberculous } \\
\text { mycobacterial nodule }\end{array}$ & $\begin{array}{l}\text { Emphysema, corticosteroids, } \\
\text { bronchiectasis. Global }\end{array}$ & $\begin{array}{l}\text { Single or multiple. May be calcified. } \\
>5 \mathrm{~mm} \text { diameter. }\end{array}$ & Progressive \\
\hline \multirow[t]{2}{*}{ Pneumocystis jirovecii } & $\begin{array}{l}\text { Usually immunocompromised patients, } \\
\text { HIV, steroids etc. }\end{array}$ & \multirow[t]{2}{*}{ Single/multiple } & \\
\hline & $\begin{array}{l}\text { Very rare cause of nodules in } \\
\text { immunocompetent host. Global }\end{array}$ & & \\
\hline \multirow[t]{2}{*}{ Nocardia spp. } & May mimic TB & \multirow[t]{2}{*}{ Single or multiple } & \\
\hline & $\begin{array}{l}\text { Up to } 1 / 3 \text { cases occur in immunocompetent } \\
\text { hosts. Global }\end{array}$ & & \\
\hline Dirofilariasis & $\begin{array}{l}\text { None. Mosquito borne zoonosis, travel to } \\
\text { South East Asia }\end{array}$ & Single or multiple nodules or cavities & \\
\hline
\end{tabular}

fungal lung infection presenting with persistent lung nodule or mass at 2 centres in Texas USA and Sao Paulo Brazil respectively [16]. All cases were referred for investigation of suspected malignancy. Diagnoses included histoplasmosis (26\%), coccidioidomycosis (22 \%), cryptococcosis (22 \%), aspergillosis (15\%), blastomycosis (7\%), mucormycosis (4\%) and paracoccidioidomycosis (4\%). Fourteen (52\%) of patients had a past history of treated malignancy and 15 (56 \%) were symptomatic at presentation. Thirteen (48\%) of patients had cough, 7 (26\%) had chest pain and 7 (26\%) weight loss. Increased PET avidity was noted in all patients and all patients demonstrated radiological improvement or resolution with appropriate antifungal therapy.

The diagnosis of an Aspergillus nodule may be challenging. Almost one third of patients did not have a positive Aspergillus IgG, and only $12 \%$ had detectable Aspergillus fumigatus precipitins. Additionally the clinical features may be non-specific, and similar to those in patients presenting with malignant disease. In this study, cough alone was the most common clinical finding. The demographics of the patients diagnosed with Aspergillus nodules are also similar to those diagnosed with malignant conditions of the lung. Our centre previously reported on the PET imaging in patients with CPA [17]. In that series all of the

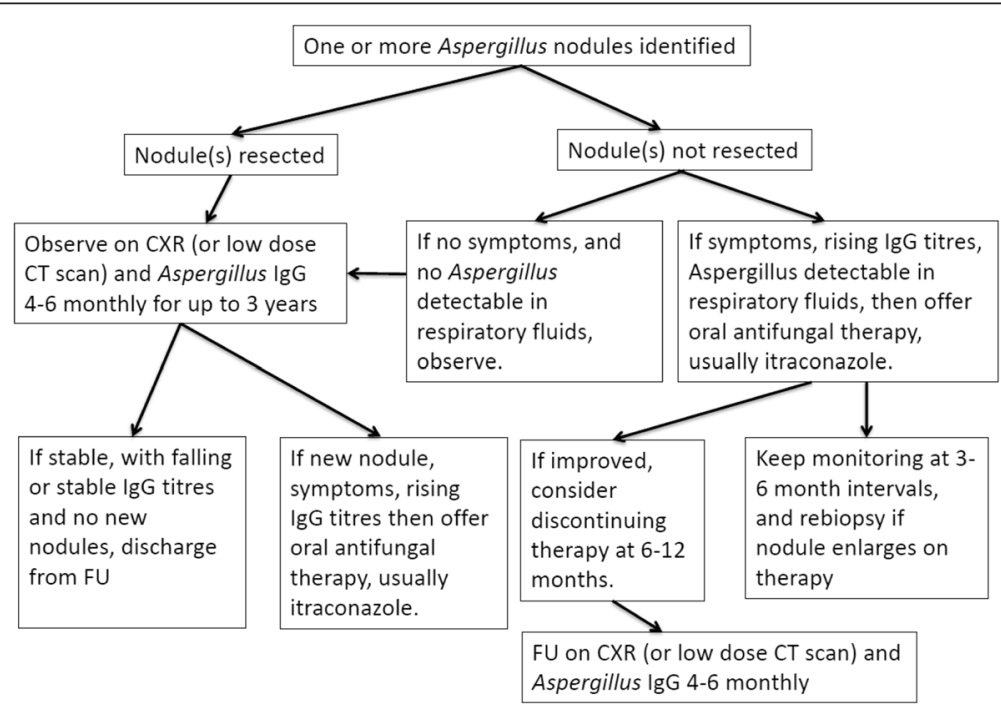

Fig. 4 Current management algorithm for Aspergillus nodules. CXR= chest radiograph; $C T=$ computed tomography; FU = follow up 
patients had positive PET imaging. Only a small number of patients in this current series had PET scans available for review, but all eight were positive with low-moderate FDG uptake.

This study is limited by being a retrospective review. Case finding was challenging, and despite a number of sources being utilised to identify cases, it is possible some cases were missed. However, this is the largest series of Aspergillus nodules published to date, and the only study to correlate radiology and histology findings with clinical features and laboratory parameters, in particular Aspergillus IgG. In patients with chronic cavitary pulmonary aspergillosis, we found the ImmunoCap Aspergillus IgG assay to be $96 \%$ sensitive and $98 \%$ specific at a cutoff of $20 \mathrm{mg} / \mathrm{L}$ and $88 \%$ sensitive and $100 \%$ specific at the current manufacturer's cutoff of $40 \mathrm{mg} / \mathrm{L}$, compared to a healthy younger control population [15]. So 69 to $81 \%$ of patients in this series had positive Aspergillus IgG serology, depending on the cutoff used [18]. This further highlights this previously lesser recognised manifestation of CPA.

The natural history of an Aspergillus nodule is not known. We are unable to define how long they were present before they came to medical attention, but we suspect months. We do know that some of the nodules remain stable off therapy for months or years after diagnosis. In general we treated the symptomatic patients, especially those with multiple lesions. Detection of Aspergillus in airways with culture or PCR also influenced us to treat, especially in those with difficult to control asthma or ABPA. We will report long term outcomes in a subsequent paper. We summarise our current approach to management in Fig. 4.

\section{Conclusion}

Pulmonary nodules are a less frequent manifestation of chronic pulmonary aspergillosis in immune competent patients. The natural history of these nodules is not yet defined. In this series, cough alone was a common presenting symptom. It may be difficult to distinguish Aspergillus nodules from other pathology on CT findings alone, and PET imaging would seem to be non discriminatory. Additionally, a significant proportion of these patients do not have a detectable Aspergillus IgG, meaning biopsy is necessary to exclude malignant disease. However, chronic pulmonary aspergillosis, should be a differential diagnosis in patients presenting with single or multiple pulmonary nodules.

\section{Abbreviations}

BAL, bronchoalveolar lavage; CCPA, chronic cavitary pulmonary aspergillosis; CFPA, chronic fibrosing pulmonary aspergillosis; CNPA, chronic necrotising pulmonary aspergillosis; CPA, chronic pulmonary aspergillosis; $\mathrm{CT}$, computer tomography; FDG, fluorodeoxyglucose; NAC, National Aspergillosis Centre; PET, positron emission tomography; SAIA, subacute invasive pulmonary aspergillosis; $\mathrm{TB}$, tuberculosis

\section{Acknowledgements}

We would like to thank Mrs Chris Harris, for her help in data collection and case finding.

\section{Funding}

This project has no funding sources.

Availability of data and material

The data set is held in the NAC, and is not publically available as it contains patient identifiable details.

\section{Authors' contributions}

EGM data collection \& analysis, wrote the paper, clinical care of patients, AS radiology review of all patients, IP case finding, data collection, PB histology review of all patients, DWD clinical care of patients, final review and approval of manuscript. All authors read and approved the final manuscript.

\section{Competing interests}

The authors declare that they have no competing interests.

\section{Consent for publication}

No patient identifiable material is presented.

\section{Ethics approval and consent to participate}

This was a retrospective service evaluation of all patients managed with pulmonary nodules and as such is exempt from ethics approval. The study was checked using the NHS medical research council/health research authority online system, and deemed NOT research.

\section{Author details}

'The National Aspergillosis Centre, University Hospital of South Manchester, 2nd floor ERC, Southmoor Road, Wythenshawe M23 9LT, UK. ${ }^{2}$ The Department of Radiology, University Hospital of South Manchester, Southmoor Road, Wythenshawe M23 9LT, UK. ${ }^{3}$ The Department of Histopathology, University Hospital of South Manchester, Southmoor Road, Wythenshawe M23 9LT, UK. ${ }^{4}$ The University of Manchester and the Manchester Academic Health Service Centre, University Hospital of South Manchester, Southmoor Road, Wythenshawe M23 9LT, UK.

Received: 27 February 2016 Accepted: 2 August 2016

Published online: 18 August 2016

\section{References}

1. Kosmidis C, Denning DW. The clinical spectrum of pulmonary aspergillosis. Thorax. 2015;70(3):270-7. doi: 10.1136/thoraxjnl-2014-206291. Epub 2014 Oct 29.

2. Denning DW, Riniotis K, Dobrashian R, et al. Chronic cavitary and fibrosing pulmonary and pleural aspergillosis: case series, proposed nomenclature change, and review. Clin Infect Dis. 2003;37 Suppl 3:S265-280.

3. Denning DW, Pleuvry A, Cole DC. Global burden of chronic pulmonary aspergillosis as a sequel to pulmonary tuberculosis. Bull World Health Organ. 2011;89:864-72.

4. Denning DW, Pleuvry A, Cole DC. Global burden of chronic pulmonary aspergillosis complicating sarcoidosis. Eur Respir J. 2013;41:621-6.

5. Smith NL, Denning DW. Underlying conditions in chronic pulmonary aspergillosis including simple aspergilloma. Eur Respir J. 2011;37:865-72.

6. Denning DWP, Pegorie M, Welfare $W$. The burden of invasive and serious fungal disease in the UK. 24th European Congress of Clinical Microbiology and Infectious Diseases. Barcelona, Spain. 2014.

7. Yasuda M, Nagashima A, Haro A, et al. Aspergilloma mimicking a lung cancer. Int J Surg Case Rep. 2013;4:690-2.

8. Ahn BC, Lee SW, Lee J, et al. Pulmonary aspergilloma mimicking metastasis from papillary thyroid cancer. Thyroid. 2011;21:555-8.

9. Kang EY, Kim DH, Woo OH, et al. Pulmonary aspergillosis in immunocompetent hosts without underlying lesions of the lung: radiologic and pathologic findings. AJR Am J Roentgenol. 2002;178:1395-9.

10. Yoon SH, Park CM, Goo JM, et al. Pulmonary aspergillosis in immunocompetent patients without air-meniscus sign and underlying lung disease: CT findings and histopathologic features. Acta Radiol. 2011;52:756-61.

11. Hansell DM, Bankier AA, MacMahon H, et al. Fleischner Society: glossary of terms for thoracic imaging. Radiology. 2008;246:697-722. 
12. England PH. UK Standards for Microbiology Investigation. 2015.

13. Fraczek MG, Kirwan MB, Moore CB, et al. Volume dependency for culture of fungi from respiratory secretions and increased sensitivity of Aspergillus quantitative PCR. Mycoses. 2014:57:69-78.

14. Sapienza LG, Gomes MJ, Maliska C, et al. Hemoptysis due to fungus ball after tuberculosis: A series of 21 cases treated with hemostatic radiotherapy. BMC Infect Dis. 2015;15:546.

15. Rolston KV, Rodriguez S, Dholakia N, et al. Pulmonary infections mimicking cancer: a retrospective, three-year review. Support Care Cancer. 1997:5:90-3.

16. Guimaraes MD, Marchiori E, de Souza Portes Meirelles G, et al. Fungal infection mimicking pulmonary malignancy: clinical and radiological characteristics. Lung. 2013;191:655-62.

17. Baxter CG, Bishop P, Low SE, et al. Pulmonary aspergillosis: an alternative diagnosis to lung cancer after positive [18F]FDG positron emission tomography. Thorax. 2011;66:638-40.

18. Page IKR, Richardson M, Denning DW. Comparative efficacy of five Aspergillus-specific IgG ELISAs for the diagnosis of Chronic Pulmonary Aspergillosis (CPA), 25th Meeting of the European Society of Clinical Microbiology and Infectious Diseases. Copenhagen, Denmark. 2015.

Submit your next manuscript to BioMed Central and we will help you at every step:

- We accept pre-submission inquiries

- Our selector tool helps you to find the most relevant journal

- We provide round the clock customer support

- Convenient online submission

- Thorough peer review

- Inclusion in PubMed and all major indexing services

- Maximum visibility for your research

Submit your manuscript at www.biomedcentral.com/submit
Biomed Central 